\title{
Ser ou não ser: a invenção do artista na gravura popular
}

Everardo Ramos

\section{Resumo}

No Brasil, a história da gravura popular pode ser dividida em dois grandes períodos. No primeiro, em que ela serve de ilustração a periódicos e folhetos de cordel, pouca ou nenhuma importância é dada aos gravadores, que vivem como simples artesãos às margens do reconhecimento oficial. Na segunda, exposições, publicações e vendas levam a gravura a museus, coleções e galerias, no Brasil e no exterior, tornando-a uma categoria reconhecida da arte, e alçando seus autores ao estatuto de artista. O presente trabalho analisa esse processo, investigando permanências e transformações ocorridas no processo de "invenção" do artista na gravura popular brasileira.

Palavras-chave: Arte popular, gravura popular, artista popular, arte brasileira.

\section{Abstract}

In Brazil the history of popular engraving may be divided into two periods. The first comprises a time during which engraving was used as illustration for periodical and cordel booklets with none or almost no acknowledgement to the engravers themselves, who lived as ordinary craftsmen on the margins of official recognition. The second time will have exhibitions, publishings and sales taking engraving to museums, collections and galleries in Brazil and abroad, which not only made engraving become an acknowledged category of art but also its producers reached the status of artists. The current paper analyses this very process and investigates settlements and transformations which occurred during the "invention" of the artist in Brazilian popular engraving.

Keywords: Popular art, popular engraving, popular artist, brazilian art. 
No Brasil, a história da gravura popular pode ser dividida em dois grandes períodos. O primeiro corresponde ao surgimento das primeiras obras, nos periódicos do século XIX (RAMOS, 2009), e à multiplicação de muitas outras nos folhetos de cordel da primeira metade do século XX. Nos dois casos, portanto, trata-se de uma produção que se desenvolve às margens dos modelos acadêmicos e oficiais, servindo de ilustração a impressos baratos e de grande circulação, realizados por pequenos editores e vendidos para um público muito extenso, principalmente para as camadas menos letradas da população. Nesse período, pouca ou nenhuma importância é dada aos autores das gravuras, que muitas vezes, inclusive, não se preocupam nem mesmo em assinar suas próprias obras, como é o caso de Antônio Avelino da Costa, principal ilustrador de folhetos de cordel da primeira metade do século XX (RAMOS, 2008b).

O segundo período, que se inicia nos anos 1950 e se prolonga até hoje, corresponde a uma série de transformações na história da gravura popular. Tudo começa quando intelectuais e instituições culturais "descobrem" essa produção e passam a promovê-la nos meios oficiais, junto a um público formado, dessa vez, nas camadas mais letradas da população (RAMOS, 2008a). É o período de exposições, publicações e vendas, que tiram a gravura do meio onde vinha se desenvolvendo até então - o da edição popular - para colocá-la em museus, coleções e galerias, no Brasil e no exterior, onde ela aparece como uma das grandes categorias da arte brasileira (RAMOS, 2010). Essa mudança radical, em relação às obras, se reflete naturalmente em seus autores, que passam a ser vistos e reconhecidos como verdadeiros artistas, inclusive por eles mesmos, como prova a assinatura obrigatória em qualquer gravura comprada numa loja de souvenirs hoje em dia.

Mas como se dá, de fato, essa transformação? Quais foram exatamente as mudanças - concretas ou simbólicas - ocorridas na vida e no estatuto do gravador, quando este passou a ser visto e a se ver como "artista" e, mais particularmente, como "artista popular"?

O presente trabalho tentará responder a essas questões, analisando e comparando o percurso de dois personagens emblemáticos da história mais recente da gravura popular, e da arte popular brasileira como um todo: Mestre Noza, o primeiro gravador a ser plenamente reconhecido como artista, e J. Borges, sem dúvida o mais famoso dos gravadores atuais. Espera-se, assim, mostrar que a "invenção" do artista, nos moldes da cultura oficial, adquire contornos particulares no âmbito da cultura popular, oscilando entre a permanência de práticas tradicionais e o surgimento de estratégias inovadoras, que redefinem as relações do criador com sua obra, seu público e, até, consigo mesmo. 


\section{Mestre Noza ou a sina de ser artesão}

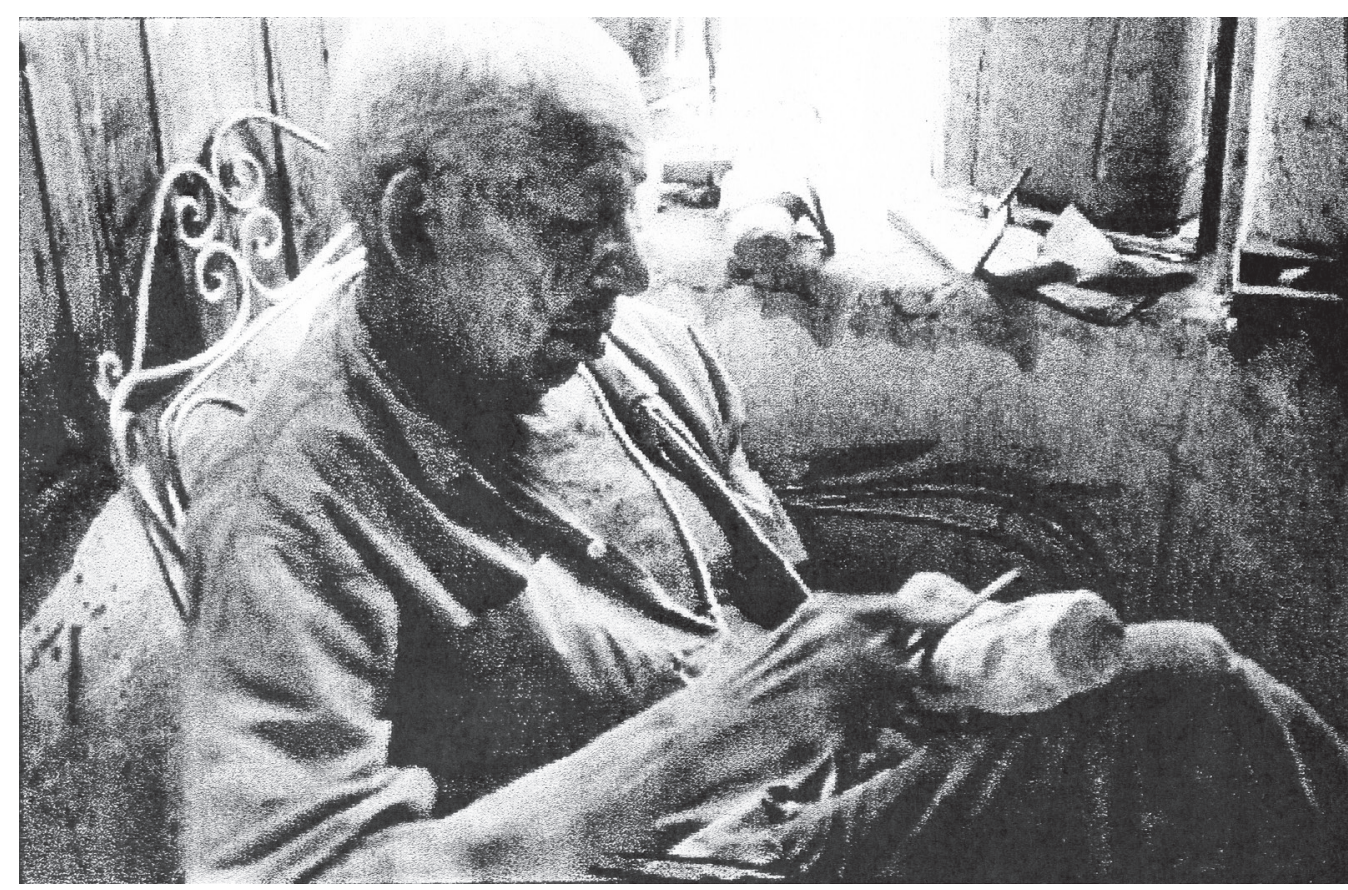

Mestre Noza em seu ateliê (anos 1970). Fotografia do Museu da Imagem e do Som (Fortaleza) (1)

Inocêncio da Costa Nick, mais conhecido como Mestre Noza, nasceu em torno de 1897, em Taquaritinga do Norte, Estado de Pernambuco ${ }^{22}$. Aos quinze anos, sua família se muda para Juazeiro do Norte, no Ceará, onde ele começa a trabalhar como artesão:

Isso foi em 1912, depois de uma romaria. Foram 600km de estrada à [sic] pé - dezesseis dias de viagem. Aqui [em Juazeiro] comecei trabalhando nos roçados e depois pendi para o ofício de funileiro, até que eu roubei uma moça e tive que enfrentar a confusão que deu. Pra ir melhorando minha situação, resolvi ser imaginário [escultor de imagens]. Por precisão, fiz um São Sebastião que logo troquei por um carneiro. [...] Aqui só duas coisas dão para viver: comércio e arte. Hoje, minha roça é o mercado. (COIMBRA et alii, 1980, p. 228)

22 A Sérvulo Esmeraldo, que faz um levantamento dos gravadores populares de Juazeiro do Norte, em 1962, Mestre Noza diz que "em 1900 tinha mais ou menos 3 anos", acrescentando que foi batizado em Poção (outro município de Pernambuco): ver Notas sôbre os Gravadores Populares, sem data, documento conservado nos arquivos do Museu de Arte da Universidade do Ceará, em Fortaleza, na pasta "Documentos Relativos às Gravuras por Sérvulo Esmeraldo". Vale salientar a importância deste documento, que registra, ao que sabemos, as primeiras entrevistas feitas com gravadores populares brasileiros. 
Ainda segundo o próprio Mestre Noza, uma vizinha lhe ensinou o alfabeto, mas ele aprendeu a ler sozinho. Quanto à profissão de “imaginário”, diz ter aprendido em 19 dias de trabalho na casa do mestre santeiro José (Imaginário) Domingos ${ }^{23}$.

As primeiras gravuras de Noza datariam dos anos 1920, quando ele se improvisa xilógrafo - certamente por já trabalhar com madeira, esculpindo imagens de santos para criar ilustrações de folhetos de cordel, atendendo às encomendas de José Bernardo da Silva, editor de Juazeiro do Norte. Também chega a gravar rótulos de aguardente, mas sua principal atividade continua sendo a escultura, principalmente a produção de estátuas de Padre Cícero (personalidade e símbolo da cidade) e de cabos de revolver, que se tornam sua "especialidade". Sua vida é, portanto, a de um simples artesão, que precisa muitas vezes exercer outras atividades para completar o orçamento do mês: entre os anos 1950 e 1960, ele trabalha como porteiro de cinema e torna-se, graças à ajuda de uma família influente da cidade, funcionário do Juizado de Menores, função na qual viria a se aposentar.

Em 1962, no entanto, a vida de Mestre Noza começa a dar uma grande guinada, em razão do processo de valorização da gravura popular nos meios letrados. Nesse ano, Sérvulo Esmeraldo, artista cearense de carreira internacional, chega a Juazeiro do Norte com o intuito de estimular a produção local de gravura popular ${ }^{24}$ (ESMERALDO, 1997). Para isso, faz um levantamento dos gravadores existentes na cidade e descobre o ateliê de Noza, conseguindo convencê-lo a gravar uma série temática sobre a Via Sacra, com as passagens da Paixão de Cristo. A iniciativa reveste um caráter pioneiro, já que a obra encomendada não se destina mais a ilustrar folhetos de cordel, mas a ser publicada em forma de álbum. A intenção é, assim, conquistar um novo público para a xilogravura de Juazeiro do Norte, junto aos admiradores da arte popular, geralmente pessoas letradas e das classes mais abastadas da sociedade ${ }^{25}$.

Em posse das matrizes gravadas, Sérvulo Esmeraldo volta à França, onde residia há alguns anos, e procura um editor que acredite em seu projeto. Depois de três anos de contatos, em 1965, seu esforço resulta no álbum Via Sacra Gravada por Mestre Noza

23 As informações sobre Mestre Noza foram retiradas de Casimiro (1997), Coimbra et alii (1980) e Souza (1981), além do documento citado na nota anterior.

24 Sérvulo Esmeraldo se associa, nesse projeto, à Universidade do Ceará, que havia iniciado o movimento de valorização da gravura popular do Estado em 1960, como tivemos a oportunidade de analisar em outro estudo (RAMOS, 2010).

25 Além da Via Sacra, Sérvulo Esmeraldo encomenda mais duas séries de gravuras a Mestre Noza: uma sobre os Apóstolos e outra sobre a Vida de Lampião. As matrizes dessas obras, compradas pela Universidade do Ceará, só seriam publicadas em forma de álbum no final dos anos 1970 (Os Doze Apostolos Gravado por Mestre Noza Juazeiro CE Brasil 1962 e Vida de Lanpiao [sic] Virgulino Ferreira Gravada por Mestre Noza Juazeiro CE Brasil 1962, ambos publicados em 1979). 
Brasil, publicado por Roberto Morel, editor especializado em bibliofilia. Além das 14 gravuras de $\mathrm{Noza}^{26}$, o álbum traz também um texto anônimo sobre a paixão de Cristo, uma oração popular bretã do século XVI e dois textos assinados pelo próprio Esmeraldo, apresentando a gravura popular brasileira e o próprio Mestre Noza. O projeto gráfico da obra é bastante requintado: as gravuras são reproduzidas impecavelmente, sobre dois tipos de papéis especiais (papier de chanvre e vélin d'arches), e o álbum é encadernado com capa dura de tela branca. Sendo obra de bibliofilia, a edição é limitada e todos os exemplares são numerados.

Essa publicação teria uma enorme repercussão no Brasil, influindo diretamente na vida e na obra de Mestre Noza. De fato, com o prestígio do álbum francês, o gravador passa a receber diversas encomendas de novas Vias Sacras, sendo uma delas publicada no Brasil, também em edição de luxo ${ }^{27}$. Em 1969, Noza merece um verbete no prestigioso Dicionário das Artes Plásticas no Brasil, realizado pelos principais críticos de arte da época (PONTUAL, 1969). Em 1970, juntamente com outro gravador popular, Walderêdo Gonçalves, vira tema do documentário Os Imaginários, do cineasta Geraldo Sarno, realizado com apoio do IEB/USP. Seu ateliê em Juazeiro do Norte se torna ponto de encontro de colecionadores, pesquisadores e turistas de toda parte, tendo Mestre Noza uma preferência particular pelos franceses, certamente em virtude do álbum que o alçou ao sucesso em $1965^{28}$. Enfim, esse sucesso acaba repercutindo além de Mestre Noza, estimulando a encomenda de novas obras também a outros gravadores, no Ceará e em outros Estados, o que possibilitou dar um novo impulso à gravura popular brasileira ${ }^{29}$.

Assim, a nova situação vivida por Mestre Noza e por seus colegas de profissão revelam uma mudança significativa no estatuto do gravador popular brasileiro. Até os anos 1960, quando trabalhava para a edição popular, realizando ilustrações de folhetos de cordel, esse gravador não beneficiava de nenhum prestígio em particular, vivendo

\footnotetext{
26 Vale ressaltar que os dados de impressão, na penúltima página do álbum, especificam que as xilogravuras de Mestre Noza "nunca tinham sido reproduzidas antes".

27 A informação vem de Coimbra et alii (1980, p. 229): “Em 1973, a Via-Sacra de Mestre Noza - edição brasileira - era citada pela revista Visão e situada entre "presentes raros e caros" ". As autoras, que entrevistaram Mestre Noza em 1975, não dão, no entanto, referências sobre a revista Visão (sabe-se apenas que era especializada em finanças e economia, e publicada em São Paulo), nem sobre a edição brasileira da Via Sacra.

28 O próprio Noza teria afirmado: “Os franceses têm sido muito bons para mim. Quando chega um deles ao pé da escada, diz logo: francês! Porque sabe que eu gosto” (CASIMIRO, 1997, s. p.).

29 A própria multiplicação de séries temáticas, na gravura popular realizada a partir dos anos 1970, revela a influência do modelo inaugurado por Mestre Noza (RAMOS, 2005b, 152-167). Da mesma forma, o tema da Via Sacra se torna quase obrigatório no repertório dos gravadores, como provam as séries sobre esse tema realizadas por Antônio Batista Silva, Walderêdo Gonçalves, José Costa Leite, Abraão Batista, Stênio Diniz e toda a nova geração de gravadores de Juazeiro do Norte, surgida nos anos 1990. Sobre essa nova geração, ver o catálogo da exposição A Nova Gravura de Juazeiro do Norte. Coleção Gilmar de Carvalho (1999).
} 
anonimamente, às margens do reconhecimento oficial. Com a intervenção de intelectuais e instituições interessadas em promover a gravura popular, no entanto, essa situação muda radicalmente: os autores das obras começam a ser conhecidos, reconhecidos e valorizados, beneficiando de um prestígio que, no caso de Mestre Noza em particular, atinge mesmo o exterior. Passando da condição de artesãos à de artistas, os gravadores populares vêem seus nomes finalmente inseridos no cenário da arte brasileira.

Mas será que esse novo estatuto trouxe mudanças concretas, reais, no trabalho e na vida dos gravadores?

O exemplo de Mestre Noza, certamente o xilógrafo popular mais conhecido de sua época, é bastante revelador. De fato, apesar de todo o sucesso que passa a gozar com sua gravura, ele continua trabalhando no mesmo ateliê onde realiza as estátuas de Padre Cícero e os cabos de revolver, num minúsculo cômodo de cerca de nove metros quadra$\operatorname{dos}^{30}$. Não há muita diferença, inclusive, na maneira de Mestre Noza criar esses diferentes tipos de obras: seja na gravura, na escultura ou na confecção de cabos de revolver, a matéria-prima é sempre a imburana, madeira local extremamente fácil de se trabalhar, que possibilita a utilização de instrumentos bastante simples (canivetes, serras, machadinhas, formões e limas). A maior diferença talvez seja o fato de que, para as estátuas e cabos de revolver, Noza conta com a ajuda de duas colaboradoras, que fazem a parte inicial do trabalho, antes da finalização e acabamento do Mestre.

Interessa notar ainda que Noza também não diferencia as obras na hora de fazer comércio, vendendo suas madeiras gravadas da mesma forma que as esculpidas, sem aproveitar o que caracteriza e particulariza o processo da gravura, ou seja, a possibilidade de conservar a matriz gravada e de vender apenas a estampa resultante da impressão dessa matriz, multiplicando assim a imagem inicial. Alguns colecionadores tentam convencê-lo a mudar de atitude, mas não obtêm sucesso:

[Eu] havia adquirido uma Via Sacra em tacos de 15 centímetros. Stênio Diniz [outro gravador popular de Juazeiro do Norte, bem mais jovem que Mestre Noza] me meteu na cabeça a idéia de que o melhor que poderíamos fazer pelo Noza era convencê-lo a não mais vender tacos e sim cópias de impressão. Terminei por devolver-lhe a coleção. Pouco tempo depois soube que o Noza vendera o conjunto ao primeiro gringo que lhe aparecera. (CASIMIRO, 1997, s. p.)

Assim, não fazendo a distinção entre "artesanato" e "arte", concebendo sua obra

30 Uma descrição detalhada do ateliê de Mestre Noza é dada por um colecionador que freqüentou assiduamente o local, nos anos 1970 (CASIMIRO, 1997). 
como resultado de um trabalho mais manual (de transformação da madeira ${ }^{31}$ ) do que simbólico (de criação de uma imagem artística), Mestre Noza são somente vende todas suas matrizes gravadas, mas também as vende por um preço irrisório. Para a sua primeira série sobre a Via Sacra, por exemplo, encomendada por Sérvulo Esmeraldo em 1962, ele pede trezentos e cinqüenta cruzeiros, dez vezes menos do que Esmeraldo estava prestes a pagar:

Quando fui pagá-lo, dei ao Mestre três mil e quinhentos cruzeiros. Relutou em receber. Tive que explicar que aquele era o preço justo e que doravante aquele valor deveria servir de base para a cobrança do seu trabalho. (ESMERALDO, 1997, p. 5)

O gravador, no entanto, não mudaria muito sua atitude, continuando a subestimar o valor de suas obras. Quatorze anos mais tarde, em 1976, um grande admirador de Mestre Noza, ao receber um extenso lote de esculturas e gravuras, se sentiu na obrigação de pagar muito mais do que o artista estava acostumado a receber, para fazer justiça à sua arte: "Paguei ao Noza, regiamente, porque sempre deplorei que sua arte fosse tão mal remunerada e [ele] vivesse quase a implorar a caridade pública" (CASIMIRO, 1997, s. p.). Portanto, apesar de ser o gravador popular de maior sucesso nos anos 1960 e 1970, beneficiando de uma notoriedade nacional e internacional, Mestre Noza continua vivendo de maneira extremamente simples, como no tempo em que criava suas obras de maneira anônima, longe do reconhecimento oficial. Aliás, tirando essa notoriedade, quase nada o diferencia dos inúmeros artesãos da cidade do Padre Cícero, todos trabalhando em ateliês pequenos e mal equipados, com pouquíssimos recursos, e ganhando muito pouco pelo fruto de seu trabalho. Para Mestre Noza, no entanto, a idade avançada e o agravamento dos problemas de saúde tornariam essa situação insustentável. Assim, no início dos anos 1980, ele se vê obrigado a deixar Juazeiro do Norte, contra sua vontade, para ir viver sob os cuidados de suas filhas que moram em São Paulo, onde morre, meio esquecido, em 1984.

\section{J. Borges ou a arte de ser popular}

José Francisco Borges, ou J. Borges, nasceu em 20 de dezembro de 1935, em Bezerros, Estado de Pernambuco, no seio de uma família de pobres agricultores: segundo seu testemunho, com apenas oito anos de idade ele já ajudava o pai nas plantações. Seus estudos se limitam a dez meses de escola, onde aprende os rudimentos da leitura e da

31 O depoimento de outro xilógrafo, Antônio Lucena (nascido em 1931), corrobora a concepção artesanal que o gravador popular pode ter de seu trabalho. Indagado sobre o tempo de execução de uma xilogravura, Lucena respondeu: "Tem xilogravura que gasta mais de um dia. É por isso que às vezes eu cobro mais caro. Eu me baseio numa diária de carpinteiro, quando eu trabalho numa obra. Eu cobro assim, uma diária ou mais" (entrevista concedida ao autor, em 24/09/2000). 
matemática. Em seguida, exerce diversas profissões - vendedor de jogo de bicho, peão de usina, marceneiro, pedreiro, carpinteiro, pintor - até que, em 1956, ingressa no universo da edição popular: primeiro como vendedor de folhetos de cordel nas feiras da região, depois como poeta (seu primeiro folheto é publicado em 1964) e, finalmente, como editor, com sua Folhetaria Borges, ativa em Bezerros (PE) a partir dos anos 197032.

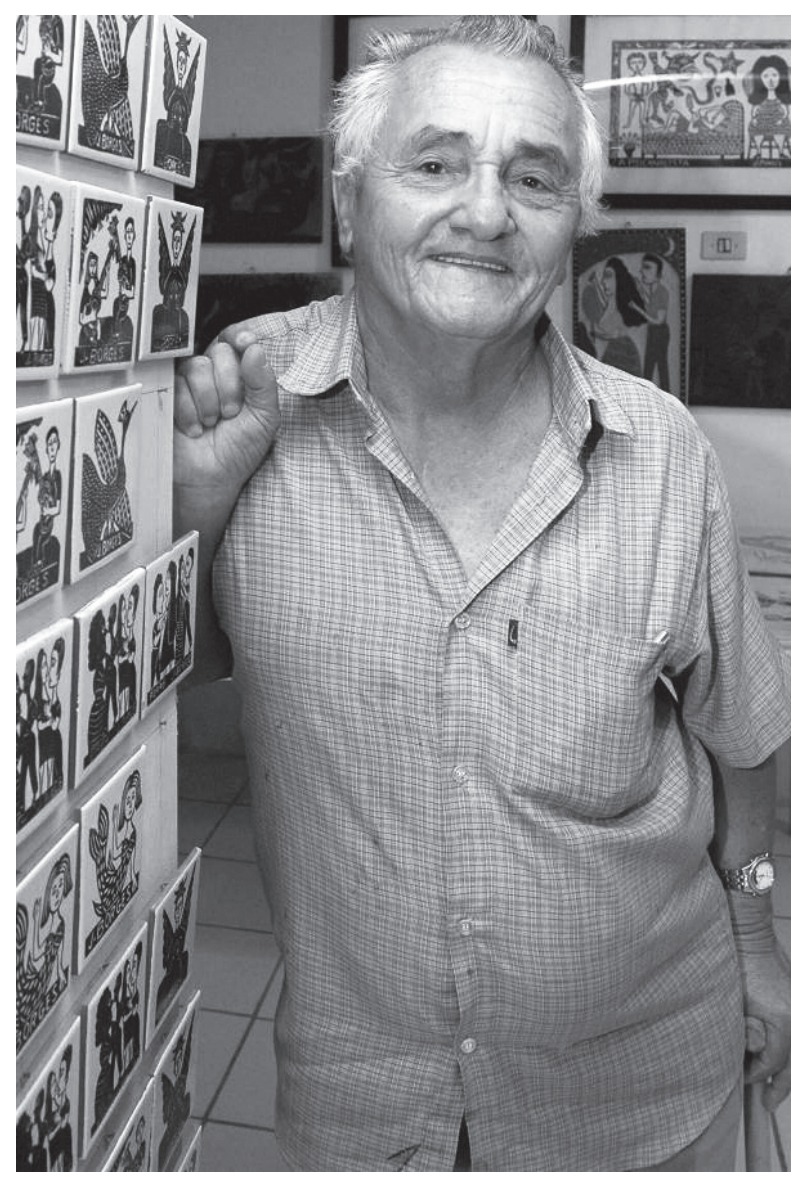

J. Borges em seu ateliê (anos 2000).

Fotografia www.onordeste.com.

Sua carreira de gravador começa por necessidade, quando ele resolve diminuir os custos de produção dos folhetos gravando as imagens de ilustração na madeira, de maneira totalmente improvisada: "Pela dificuldade de conseguir os clichês para os meus Folhetos, eu mesmo resolvi plainar um pedaço de madeira e fazer minha primeira xilogravura" (BORGES e COIMBRA, 1996, p. 24). Com o tempo, no entanto, a gravura iria desempenhar um papel cada vez mais importante na vida de J. Borges, vindo a tornar-se sua principal atividade e sua maior fonte de renda.

32 J. Borges publicou duas autobiografias com diversas informações sobre sua vida e sua obra: Borges e Coimbra (1996) e Borges (2002). 
Esse processo se dá em duas fases. A primeira começa no início dos anos 1970, quando artistas e intelectuais "descobrem" J. Borges e passam a encomendar-lhe gravuras que não se destinam mais à ilustração de folhetos ${ }^{33}$. Algumas dessas obras dão origem a dois álbuns prestigiosos, de que participam importantes personalidades da cultura pernambucana: Ariano Suassuna, por exemplo, assina os textos de apresentação, afirmando que J. Borges é "o maior gravador popular do Nordeste" ${ }^{4}$. Borges também realiza um grande número de xilogravuras - vendendo as matrizes gravadas em madeira, como fazia Mestre Noza - para Giuseppe Bacarro e sua fundação filantrópica Casa das Crianças de Olinda, bem como para Carlos Ranulpho, galerista que, realizando as primeiras grandes exposições de gravura popular pelo Brasil, inicia o comércio dessa arte em grande escala ${ }^{35}$. Enfim, o reconhecimento da obra de J. Borges se traduz pela utilização de suas gravuras na abertura da novela Roque Santeiro, da famosa TV Globo ${ }^{36}$.

Nessa primeira fase, portanto, Borges participa do movimento de valorização da gravura popular pelos meios letrados, que acontecia ao mesmo tempo no Ceará, onde se destacava Mestre Noza. E assim como no caso de Noza, a participação nesse movimento fez com que J. Borges saísse do anonimato em que vivia como simples ilustrador de folhetos, para revelar-se ao público admirador da arte popular, formado essencialmente por pessoas das classes sociais mais elevadas. Ao contrário de Mestre Noza, no entanto, essa transformação traria mudanças importantes para o gravador pernambucano, melhorando visivelmente seu nível de vida, como mostra o depoimento de seu irmão, Amaro Francisco, que se iniciaria na gravura popular influenciado pelo sucesso de J. Borges, em torno de 1972:

[J. Borges] chegou em Escada [cidade onde vivia Amaro Francisco]: chapéu bonito, pé no sapato, roupa boa, bolsa de lado... Eu digo: "Ói rapaz, melhorasse a situação? Pegasse a loto, foi?”. Ele disse: "Nada, rapaz, eu tô noutra". Ele propagou cordel vinte anos, na feira, mas dessa vez apareceu essa "bocada de xilogravura", como ele dizia.

33 "Em 1972 surgiram vindos do Rio de Janeiro, os pintores paisagistas Ivan Marqueti e José Maria de Souza que visitando-me em Bezerros se depararam comigo fazendo capas de Folhetos. Gostaram muito do meu trabalho e acabaram encomendando várias gravuras em tamanhos maiores com temas ao meu inteiro critério" (BORGES e COIMBRA, 1996, p. 27).

34 O primeiro álbum é A Vida do Padre Cícero Gravada por José Borges (1972), s. p, organizado por Liêdo Maranhão e com projeto gráfico de Gilvan Samico. O outro álbum, J. Borges - 10 gravuras (1973), foi publicado pelo galerista Carlos Ranulpho, com projeto gráfico ainda mais requintado: a obra tem capa dura, grandes dimensões ( $45 \times 47 \mathrm{~cm}$ ) e as gravuras são montadas com passe-partout.

35 Analisamos longamente as atividades de Giuseppe Baccaro e Carlos Ranulpho relacionadas à gravura popular, em outro estudo (RAMOS, 2005a, p. 342-354).

36 A novela, no entanto, não iria ao ar, censurada pelos militares no poder. Somente dez anos depois, já com a redemocratização, Roque Santeiro seria transmitida, mas numa nova versão e com uma nova abertura. 
Então ele chegou, foi me explicar o que era xilogravura. Eu não entendia. Ele disse: "Vai lá em casa que eu te mostro". (Depoimento de Amaro Francisco ao autor, em 20/08/2000)

Essa fase de prosperidade, no entanto, acabaria progressivamente, à medida que a gravura popular vai deixando de ser uma "novidade", o que provoca uma diminuição radical nas vendas e encomendas. A situação chega a tal ponto que, em 1990, J. Borges se vê obrigado a escrever uma carta a Ariano Suassuna, seu "padrinho" artístico, pedindo-lhe para intervir na imprensa e junto aos governantes, a fim de encontrar uma solução para a crise. Nesta carta, efetivamente divulgada pela imprensa (MACIEL, 1990), ele não se refere, no entanto, especificamente à gravura, mas à crise na edição de folhetos, que ameaça fechar as portas de sua Folhetaria Borges, apresentada como a última em funcionamento no Nordeste. Para ele, a razão dessa crise não era a falta de interesse do público, mas os custos de produção:

Os revendedores me dizem que a procura nas feiras e praças atinge a um público de seis a 80 anos, numa visão clara de que o cordel está forte da demanda e morre por falta de alimento na produção. (MACIEL, 1990, p. 6)

No ano seguinte, J. Borges volta a ocupar as páginas dos jornais do Recife (PEREIRA, 1991; PRADO, 1991), mas dessa vez não para lançar um novo pedido de socorro, e sim divulgar sua mais nova criação: uma série de xilogravuras para ilustrar um livro do escritor uruguaio de renome internacional, Eduardo Galeano (publicado no Brasil em 1994, com o título As palavras andantes). Para a imprensa, J. Borges descreve todos os detalhes do projeto, inclusive o acordo financeiro firmado com o escritor, que pagaria setenta dólares por gravura, o que daria, no final do trabalho, cerca de nove mil dólares por cento e cinquenta gravuras realizadas (PEREIRA, 1991, p. C-1). Para o gravador, esse novo trabalho tinha chegado no momento certo, sendo mais que providencial:

O cordel passa por uma de suas piores crises. A economia do país vai mal e o turismo caiu muito. A saída dos folhetos e das gravuras tem sido pequena. Para completar, há quatro anos venho tentando um financiamento para comprar uma impressora nova e até agora somente consegui promessas. (PEREIRA, 1991, p. C-1)

Vê-se, portanto, que J. Borges se contradiz claramente de um ano para o outro. De fato, se antes ele afirmava que a demanda de folhetos não havia diminuído, atribuindo a crise do cordel aos custos de produção, agora ele admite que "a saída dos folhetos e das gravuras tem sido pequena", sugerindo a falta de interesse do público. O jornalista que vai à Folhetaria Borges para fazer a entrevista observa, inclusive, que ela está cheia de "folhetos de cordel encalhados". Por outro lado, J. Borges reclama por não conseguir um financiamento para comprar uma prensa nova, mas diz também que utilizou o dinheiro 
já recebido de Eduardo Galeano - cerca de quatro mil dólares - para comprar um automóvel.

Isso revela a verdadeira situação vivida pelo poeta, editor e gravador popular. Se J. Borges não investe mais nos folhetos de cordel, comprando uma prensa nova com o dinheiro recebido de Eduardo Galeano, é porque sabe que isso não vai lhe trazer lucro, pois já não existe público suficiente para rentabilizar esse tipo de produção. Porque, então, ele tinha se mostrado tão apegado à edição popular, na carta dirigida a Ariano Suassuna no ano anterior? Com certeza, pelo seu amor sincero pela literatura de cordel, com a qual trabalhava há tanto tempo, mas também porque, em se apresentando com o "último editor em atividade" e alardeando o perigo de fechar suas portas, podia sensibilizar intelectuais e governantes, pleiteando financiamentos oficiais.

Seja como for, o fato de ilustrar o livro de um escritor tão famoso quanto Eduardo Galeano, traduzido em diversas línguas e publicado em diferentes países, abriria novas portas para J. Borges, principalmente no cenário internacional, marcando o início da segunda - e mais brilhante - fase de sua carreira como gravador.

Em 1992, ele é convidado a expor e a ministrar uma oficina de xilogravura ${ }^{37}$ no Museum of International Folk Art de Santa Fé, nos Estados Unidos: trata-se da primeira de uma série de viagens de J. Borges ao exterior, principalmente aos Estados Unidos, mas também à Suíça, França, Alemanha, Portugal, Cuba e Venezuela (VICTOR, 2003). Em 1999, ele recebe das mãos de Fernando Henrique Cardoso, então Presidente da República, a prestigiosa Ordem do Mérito Cultural, "por suas contribuições à cultura brasileira". Em 2002, o New York Times publica uma longa reportagem sobre o gravador popular, louvando-o como "a Master of a Folk Tradition" (ROHTER, 2002). No mesmo ano, Pablo Stalli, galerista e marchand da obra de Borges em Zurique, na Suíça, consegue incluir uma de suas gravuras no calendário de luxo distribuído pela ONU aos chefes de Estado do mundo todo.

Além da notoriedade, as novas iniciativas também representam uma importante fonte de renda para J. Borges, que melhora sensivelmente suas condições de trabalho e seu padrão de vida. Cada viagem ao exterior, por exemplo, lhe rende cerca de três mil dólares, entre pagamento de workshops e venda de gravuras (BURCKHARDT, 2002). Em 2002, ele é um dos selecionados pelo programa Patrimônio Vivo de Pernambuco, passando a receber uma pensão vitalícia do Estado. Seu ateliê começa a atrair visitan-

37 Vale salientar a importância simbólica dessa nova atividade desenvolvida pelo gravador popular, que confirma definitivamente seu novo estatuto: se, antes, ele transmitia seu saber de maneira espontânea e informal, caracterizando a própria tradição popular, agora, ele sistematiza esse saber, transmitindo-o de maneira oficial, nos moldes do sistema letrado. 
tes e compradores de toda parte, tornando-se uma das atrações turísticas de Bezerros, pequena cidade do agreste pernambucano. O sucesso é tanto que exige novos espaços, tanto físico, quanto virtual: em 2003, é inaugurado, com grande festa, o Memorial J. Borges, mistura de ateliê e museu pessoal, construído ao lado de sua casa (VICTOR, 2003); enfim, desde 2010, um site na internet divulga as obras que podem ser compradas e encomendadas no Memorial, desde as xilogravuras tradicionais, até objetos diversos canecas, blusas, caixas, etc. - ilustrados com obras do gravador ${ }^{38}$.

Gozando de um enorme prestígio nacional e internacional e beneficiando de condições materiais que o distingue muito da maioria dos artistas populares, J. Borges se apresenta hoje, portanto, como o mais conhecido e celebrado dos xilógrafos em atividade, representando um verdadeiro ícone da arte popular brasileira como um todo.

\section{Ser ou não ser: eis a questão}

Assim, ao comparar o destino de J. Borges ao de Mestre Noza, expoentes da história da gravura popular em épocas distintas (anos 1960 e 1970 para o primeiro, desde a década de 1990 para o segundo), é possível avaliar as mudanças ocorridas no estatuto e na vida do gravador a partir do momento em que passou a ser considerado artista.

Em primeiro lugar, do ponto de vista do reconhecimento e da fama, constata-se que a diferença entre os dois gravadores não é muito grande: em sua época, Mestre Noza também foi considerado um artista excepcional, fazendo muito sucesso dentro e fora do Brasil. No entanto, isso nunca lhe permitiu alçar vôos tão altos quanto os de J. Borges, tendo vivido sempre de maneira extremamente simples, com pouquíssimos recursos, recluso em sua Juazeiro do Norte. Na verdade, a única vez em que deixaria essa cidade seria, não para participar de exposições e ministrar oficinas internacionais, como J. Borges, mas para viver aos cuidados de suas filhas em São Paulo, pobre e doente.

O que poderia explicar, então, destinos ao mesmo tempo tão parecidos e tão diferentes? Mestre Noza, como vimos, sempre trabalhou como artesão, fazendo gravuras da mesma forma que esculturas: utilizando a mesma madeira, os mesmos instrumentos, e vendendo as obras prontas - matrizes gravadas ou estatuetas - ao primeiro comprador que aparecesse, por um preço calculado certamente em função de suas necessidades mais imediatas. Por outro lado, se ele não era indiferente ao sucesso - conta-se que a parede de seu ateliê ostentava fotos suas com visitantes estrangeiros, certamente motivo de grande orgulho (CASIMIRO, 1997, s. p.) -, é certo que não procurava tirar partido desse sucesso, conservando sempre uma modéstia característica. Essa atitude, aliás, seria louvada como uma prova de autenticidade do verdadeiro "artista do povo", humilde e

38 Ver http://memorialjborges.arteblog.com.br (acesso em 18/05/2012). 
sem ambição, por intelectuais imbuídos de um preconceito tipicamente folclorista: o de que a arte popular deve ser feita sem interesse pecuniário, para assegurar a "pureza" das obras ${ }^{39}$.

Já em relação a J. Borges é possível distinguir dois tipos de atitude. Na década de 1970, ele também começou agindo como artesão, vendendo suas matrizes gravadas a colecionadores e galeristas, que as utilizavam como queriam. Com o tempo, no entanto, ele aprendeu que podia se tornar o proprietário e administrador de sua própria obra, conservando as matrizes e vendendo apenas as estampas sobre papel, como faz o gravador erudito. Da mesma forma, se aconteceu de ele subestimar o preço de seus primeiros trabalhos, a experiência lhe ensinou a cobrar o que lhe parecia justo, em troca de obras e serviços. Por outro lado, ao contrário de Mestre Noza, J. Borges entendeu que a publicidade é um aliado indispensável para se destacar num mundo competitivo. Daí o cuidado de sempre divulgar cada uma de suas conquistas, de maneira a fazê-las aparecer na imprensa, e de solicitar a ajuda de personalidades da cultura e da arte nas ações de promoção pessoal ${ }^{40}$. Em contrapartida, Borges expressa sua gratidão registrando seus próprios filhos com os nomes dessas personalidades, reproduzindo relações de compadrio correntes na cultura popular nordestina ${ }^{41}$.

Enfim, é preciso destacar a grande habilidade de J. Borges para adaptar sua imagem pessoal às expectativas do novo público admirador do artista popular "autêntico". Aqui também, a comparação com Mestre Noza é bastante reveladora. Apesar de ter nascido, como Borges, numa família de pobres agricultores, Noza sempre se orgulharia de seu sobrenome, usando-o como prova de suas origens holandesas ${ }^{42}$ : "Nick [...] é uma descendência holandesa. Nem brasileiro eu sou. Não gosto de ser brasileiro, porque o brasileiro só fecha a porta quando é roubado" (TAVARES, 1997, s. p.). Por outro lado, apesar de quase analfabeto, ele se gabava de estudar francês e inglês "sem mestre", o que se confirma em uma gravura de 1962, onde ele identifica a companheira de Lampião, não como Maria Bonita, mas como Maria Joli (pronúncia da palavra "jolie”, que significa "bonita" em francês $)^{43}$. Em seguida, com a publicação de sua Via Sacra na

39 Veja-se, por exemplo, Tavares (1997). Sobre os conceitos - e preconceitos - folcloristas, analisados no contexto especificamente brasileiro, ver Vilhena (1997).

40 Todo um capítulo de seu primeiro livro autobiográfico, por exemplo, é constituído de testemunhos de admiração e amizade, assinados por personalidades da cultura pernambucana (Borges e Coimbra, 1996).

41 J. Borges deu os seguintes nomes a seus filhos, em homenagem a personalidades: Ariano (homenagem a Ariano Suassuna), Ivan Marqueti (Ivan Marquetti, pintor que o "descobriu" em 1972); Rafael (Rafael Przytyk, colecionador), Baccaro (Giuseppe Baccaro, colecionador), Joaquim (o pai de J. Borges, mas também Joaquim Falcão, presidente da Fundação Roberto Marinho, que subvencionou seu primeiro livro autobiográfico). As informações são tiradas de Moura (2002).

42 Mestre Noza, que não tinha certidão de nascimento, dizia que seu nome completo era Inocêncio da Costa Nick: ver Notas sôbre os Gravadores Populares, sem data, documento conservado nos arquivos do Museu de Arte da Universidade do Ceará, em Fortaleza, na pasta "Documentos Relativos às Gravuras por Sérvulo Esmeraldo".

43 Ver o álbum Vida de Lanpiao [sic] Virgulino Ferreira Gravada por Mestre Noza Juazeiro CE Brasil 1962 
França, que lhe abriu as portas do sucesso, a francofilia de Mestre Noza aumentaria mais ainda, como assinalamos anteriormente ${ }^{44}$.

Já a imagem que J. Borges constrói de si mesmo é o extremo oposto da de Mestre Noza. Em suas diversas entrevistas, ao invés de se orgulhar de sua inquestionável ascensão social, que o colocou na posição de um verdadeiro artista internacional, Borges sempre enfatiza suas origens sertanejas e nordestinas, apresentando-se como um matuto de pouquíssimas letras, às vezes mesmo como um analfabeto. Por ocasião da publicação de seu segundo livro autobiográfico, em 2002, ele informa à imprensa que dispensou "a ajuda de "pessoas cultas" porque prefere a presença de erros gramaticais num autêntico retrato seu e de suas verdadeiras lembranças” (MOURA, 2002). Ora, é preciso insistir sobre a artificialidade desse tipo de atitude, ainda mais quando se sabe que os grandes poetas populares sempre procuraram respeitar a língua culta, fazendo questão de corrigir seus erros a cada nova edição de um folheto (SANTOS, 2006, p. 98-100). J. Borges compreendeu, no entanto, que no contexto de valorização da cultura popular pelos meios letrados, é preciso alimentar essa imagem de artista ignorante, quase caricato, para satisfazer o novo público a que se destina ${ }^{45}$.

Portanto, a partir dos percursos e dos destinos de Mestre Noza e J. Borges, conclui-se que a "invenção" do artista no universo da gravura popular resultou num processo bastante complexo, em que se destacam dois tipos de comportamento. Por um lado, o novo artista que se manteve apegado a concepções e práticas tradicionais, definidas no tempo em que sua obra servia apenas à edição popular, não teve condições de tirar pleno benefício da valorização de sua obra e do reconhecimento de seu talento, continuando a trabalhar e a viver como qualquer artesão. Quando, no entanto, o artista compreendeu verdadeiramente as novas possibilidades abertas por essa valorização e reconhecimento, sua atitude mudou, e ele passou a adotar novos procedimentos - principalmente em termos de promoção pessoal ${ }^{46}$ - para projetar-se e alcançar patamares elevados no trabalho

(1979). Sérvulo Esmeraldo, que mora em Paris quando vai encomendar as gravuras sobre a Via Sacra a Mestre Noza, conta: "Falamos da França, perguntou muito. Sabia algumas palavras em francês. Num dado momento perguntou-me se "plastron" em francês queria dizer peito. É peito, porém, peito de camisa respondi. Ficou meio decepcionado. Disse-lhe como era peito em francês. Me pediu que escrevesse a palavra. Escrevi a palavra e a pronúncia" (ESMERALDO, 1997, p. 3).

44 Ver nota 7.

45 "Eu sei que este livro vai ser lido por um publico [sic] diversificado, como seja, professores, pesquisadores, doutores em varias [sic] áreas e até por intelectuais, e o povo em geral. [...] Se o conteúdo do poema ou da prosa não faz graça nenhuma, [...] as pessoas ainda riem com os erros de frases, e acentuação" (BORGES, 2002, p. 257).

46 Vale ressaltar as dificuldades de atuação nesse campo da promoção pessoal, mesmo para outros gravadores tão inteligentes como J. Borges. José Costa Leite, por exemplo, teve xilogravuras suas reproduzidas em um livro publicado na França em 2005, no âmbito do Ano do Brasil na França, pela Editions Chandeigne, renomada editora de obras relacionados à cultura lusófona (MOREAU e LEMOS, 2005). Em vez de alardear o fato à imprensa, em benefício de sua própria publicidade, ele simplesmente reclamou por não ter recebido 
e na vida. Esse salto, porém, se deu à custa de uma certa submissão a modelos externos, relacionados à identidade do gravador. Assim, enquanto Mestre Noza podia exibir com orgulho sua "xenofilia", uma abertura ao mundo que contradiz os clichês formados sobre o comportamento de um simples artesão, J. Borges foi obrigado a etiquetar-se de "rústico", de enfatizar seu apego às raízes, para ser considerado um "autêntico artista do povo".

Desde os estudos folclóricos iniciados no século XIX, cristalizou-se a noção de que os criadores populares, por serem geralmente autodidatas, são necessariamente ingênuos e avessos aos modelos - reais ou simbólicos - da modernidade, estando condenados a reproduzir passivamente modelos ultrapassados. Estudos mais recentes vêm, no entanto, ajudando a desfazer esse equívoco. Néstor Canclini, por exemplo, analisando manifestações tradicionais no âmbito de sociedades pós-modernas, identifica diferentes "estratégias para entrar e sair da modernidade" e mostra que "o popular não é vivido pelos sujeitos populares como complacência melancólica para com as tradições" (CANCLINI, 2011, p. 221). Os casos aqui estudados corroboram plenamente essa ideia: revelando novas nuances na relação do criador autodidata com seu trabalho, seu público e até consigo mesmo, eles provam que o gravador popular encontrou meios para inventar-se e reinventar-se artista, forjando sua história e construindo seu espaço no cenário da arte brasileira, entre o arcaico e o moderno, entre o artesanato e a arte, entre o ser e o não ser.

\section{Referências bibliográficas}

BORGES, José Francisco. Memórias e contos de J. Borges. Recife: edição do autor, 2002.

BORGES, José Francisco; COIMBRA, Sílvia Rodrigues. Poesia e gravura de J. Borges. Recife: edição do autor, 1996

BURCKHARDT, Eduardo. O artista do sertão. Época, Rio de Janeiro, edição 220, 5 de agosto de 2002. 56-57.

CANCLINI, Néstor García. Culturas híbridas. Estratégias para entrar e sair da modernidade. São Paulo: Editora da Universidade de São Paulo, 2011.

CASIMIRO, Renato. Mestre Noza, um depoimento pessoal. In: TAVARES, Iris (org.). Cem anos de Mestre Noza. Arte que o tempo não sucumbiu. Juazeiro: Fundação Memorial de Padre Cícero, 1997.

COIMBRA, Sílvia Rodrigues; MARTINS, Flávia ; DUARTE, Maria Letícia. O reinado da

nenhum benefício financeiro: "apenas me mandaram quatro exemplares do livro" (depoimento dado ao autor, em outubro de 2005). Vê-se, portanto, como as possibilidades de retorno de um "marketing pessoal" parecem por demais abstratas para o artista tradicional. 
lua. Escultores populares do Nordeste. Rio de Janeiro: Salamandra, 1980.

ESMERALDO, Sérvulo. Sobre a gravura popular e a Via-Sacra de Mestre Noza. In: TAVARES, Iris (org.). Cem anos de Mestre Noza. Arte que o tempo não sucumbiu. Juazeiro: Fundação Memorial de Padre Cícero, 1997. 1-11.

GALEANO, Eduardo. As palavras andantes. Porto Alegre: L\&PM, 1994.

MACIEL, Ayrton. Cordel pede socorro a Ariano Suassuna. Diário de Pernambuco, Recife, 29 de abril de 1990. 6.

MOREAU, Annick; LEMOS, Anne-Marie. Charlemagne, Lampião \& autres bandits. Histoires populaires brésiliennes. Paris: Editions Chandeigne, 2005.

MOURA, Ivana. J. Borges. De Bezerros para o mundo. Correio Braziliense. Brasília, 16 de abril de 2002. 18.

PEREIRA, Marcelo. J. Borges ilustra Galeano. Jornal do Commercio, Recife, 25 de agosto de 1991. C-1.

PONTUAL, Roberto. Dicionário das artes plásticas no Brasil. Rio de Janeiro: Civilização Brasileira, 1969.

PRADO, Marcus. Eduardo Galeano e J. Borges: parceria. Diário de Pernambuco, Recife, 18 de agosto de 1991. 23.

RAMOS, Everardo. La gravure populaire au Brésil (XIX $-X X^{e}$ siècle). Du marché au marchand. Tese de Doutorado. Nanterre: Université Paris X - Nanterre, 2005 (a).

Du marché au marchand. La gravure populaire brésilienne. Gravelines: Musée du dessin et de l'estampe originale, 2005 (b).

Ariano Suassuna e a gravura popular brasileira ou a (de)formação de um pensamento crítico. In: ZACCARA, Madalena; PEDROSA, Sebastião. Artes visuais: conversando sobre. Recife: Ed. Universitária da UFPE, 2008 (a). 23-43.

Ilustrações de folhetos de cordel: o romance dos esquecidos ou a peleja do popular com o moderno In: Recortes contemporâneos sobre o cordel. Rio de Janeiro: Edições Casa de Rui Barbosa, 2008 (b), 207-238.

Origens da imprensa ilustrada brasileira (1820-1850). Imagens esquecidas, imagens desprezadas. Escritos. Revista da Casa de Rui Barbosa. Rio de Janeiro: Edições Casa de Rui Barbosa, 2009, 285-309.

Do mercado ao museu. A legitimação artística da gravura popular.

Visualidades. Revista do Programa de Mestrado em Cultura Visual, V.8, nº 1. Goiânia: UFG/FAV, 2010, 38-57. 